Journal of Mathematics and Statistics 5 (1): 15-23, 2009

ISSN 1549-3644

(C) 2009 Science Publications

\title{
Simulation Planning for Sustainable Use of Land Resources: Case study in Diamou
}

\author{
${ }^{1}$ Diallo Yacouba, ${ }^{1} \mathrm{Hu}$ Guangdao and ${ }^{2}$ Abdurazak Hussien Abdulahi \\ ${ }^{1}$ Faculty of Earth Resources, China University of Geosciences, \\ 430074-Wuhan, Hubei, Republic of China \\ ${ }^{2}$ Faculty of Environment, China University of Geosciences \\ 430074-Wuhan, Hubei, Republic of China
}

\begin{abstract}
In this study, we presented the simulation planning scheme to project land and land resources use changes at a local scale for Diamou (MALI). Problem statement: All the land cover types were under the influence of human and livestock population. Diamou has undergone changes in land-cover over the last decades. The shifting cultivation system practiced was probably the main reason for this state of affairs. Moreover, the dryness and extensive character of pastoral activities had contributed to the general degradation of natural resources. The principal objective of our study was to contribute to the sustainable use of land resources from 1999-2010. Approach: Using formula the resources supply and demand had been estimated based on statistics data, derived from a comprehensive review of the literature. The resources balance (difference between supply and demand) had been estimated for two years 1999 and 2010.The resources demand were measured by an average consumption needs person ${ }^{-1}$ day $^{-1}$ multiplied by the population. For the livestock population the biomass demand and supply had been measured based on TLU dietary requirements and the pastureland carrying capacity. The diagram of resources balances were drawn using word Microsoft word command and the simulation land use areas schema using ArcGIS. Results: From present approach, it was found, that, in year 1999 the fuel wood and cereal balances were negative. The drink water and biomass balances were positive. The dominant land use categories were the pastureland and the cropland, occupying about 52 and $45 \%$ of total area respectively of the total area 8876 ha. Except the biomass balance in year 2010, all the resources balance were negative. The drink water and fuel wood deficits were equal to 439 and $2801 \mathrm{~m}^{3}$ respectively. The dominant land use class, a cropland covered approximately $45 \%$ of total area. Conclusion: Studies had indicated the cereal, fuel wood and drink water resources deficit in years 1999 and 2010.
\end{abstract}

Key words: Diamou, Planning, sustainable use, land resources, pressure

\section{INTRODUCTION}

Most land cover modification and conversion is nowadays driven by human use rather than natural change. Some locale studies have shown, that since the early 1970s, the Sahel countries have been suffering from chronic food shortages caused by economic crisis, poverty, desertification and climate changes. After Stephenne and Lambin ${ }^{[28,29]}$, the Sudano-sahelian region has undergone changes in land-cover over the last decades ${ }^{[3]}$. However, it is still debated to know whether these changes are related to short-term climate fluctuations or longer-term anthropogenic impacts ${ }^{[15,17]}$. The shifting cultivation system practiced in Diamou was probably the main reason for this state of affairs.
Moreover, the dryness and extensive character of pastoral activities, have contributed to the general degradation of natural resources. As a result, the land/man and arable land/ man ratio in Diamou decreased to 3 and 1.4 ha; respectively. Many important plant species of which Vitellaria paradoxa ( $\mathrm{Si}$ ), Prosopis africana (Guélé), Elaeis Guineensis (N'té) Oxytenanthera abyssinca (Bonego), Borarsus aethiopum (Sibo), Cordyla pinnata (Dougouto) are extremely rare and considered threatened. According to to the climate type $\mathrm{e}^{[14,17]}$ most of inventoried soils units are poorly drained, shallow with high gravel content or Massive structure, low fertility.

Some of the traditional wells dug by the end of rainy season or during the dry season were falling

Corresponding Author: Diallo Yacouba, Faculty of Earth Resources, China University of Geosciences, 430074-Wuhan, Hubei, Republic of China 
rapidly dry and children and women had to walk far away to fetch water.

The stock of its natural resources includes land, minerals, water, flora and fauna and is the backbone of the economy and the livelihoods of its inhabitants. Negative land use-cover change processes, understood as the change from any primary dominated land cover into any man-made dominated one, have largely resulted as desertification, deforestation, habitat fragmentation, biodiversity loss and eventually into global warming ${ }^{[10]}$ and reduction of environmental services ${ }^{[21]}$. In Diamou the diet is composed by cereals for up to $83^{[19]}$ of the total consumption. Local-scale studies and regional surveys estimated that $90 \%$ of the energy needs of households are covered by wood. The pastoralism is extensive, the biomass output for the livestock feeding depends on the rainfall and need to be evaluate as many others resources. Diamou remains an important economic and pastoralism center. Most studies have been focused on the land planning and land degradation, without resources estimation. The principal objective of our study was to contribute to reach the sustainable use of land resources from 1999-2010. The rest of the study is organized as follow: section two, presents the material and methods. Section three presents our simulation results. Section four presents our discussions and finally Section five, conclusion.

\section{MATERIALS AND METHODS}

The equipment needed to carry out the study is composed:

Computer and ArcGIS software: Topographic map (West Africa) at a scale 1/200000, Kayes ND-29-XIII.

The study area Diamou located in the south western part of Mali covers approximately 8876 hectares in the Kayes Region and lies between latitudes north $14^{\circ} 0^{\prime}-14^{\circ} 10^{\prime}$ and longitudes west $11^{\circ} 10^{\prime}-11^{\circ} 30^{\prime}$. Its boundaries are Balandougou in the north, Hameya in the south, Hamanda in the west and the river Senegal in the east. The climate is characterized by its sudano-sahelian type with a long dry season (September-may), divided in cool period from November to February and warm period from March to June. The main rainy season extends from June to September or mid October. As a tropical climate, it is characterized by a dry season controlled by warm and tropical air masses (Harmattan) at times of high sun and by a rainy season controlled by the continental tropical air masses (Mouson) at times of low sun. The climate data are obtained from country Meteorolocal Service.

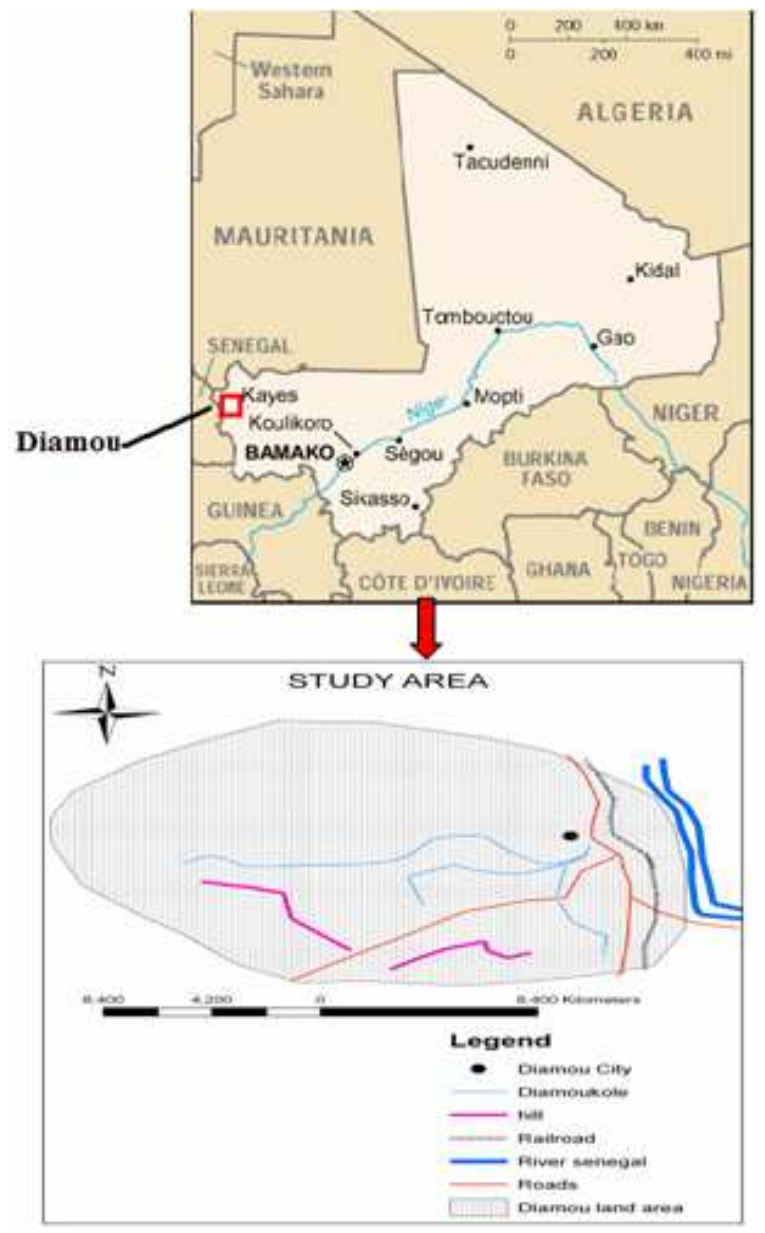

Fig. 1: Diamou location, indicated by red box is extended as a study area

The yearly average mean rainfall is about $650 \mathrm{~mm}$ and an annual average temperature is about $27^{\circ} \mathrm{C}$ with a maximum of 45 degrees Celsius. The maximum of rainfall obtained is $750 \mathrm{~mm}$ and the minimum is $550 \mathrm{~mm}$ (Fig. 1). The relief of Diamou is mostly flat with some hill slopes in its South and South-west parts. There are four land cover units/land cover types: the hill slope, The table land, the plain and the terrace land ${ }^{[21,29]}$. The Hydrology is represented by the Senegal River to the East.

The practical approach was composed by Bibliographic research or literature review and Balance estimation of water and land resources, resources chart design and developing a land-use plan.

To prepare our study methods it was necessary to find out a set of literature review. There were amongst others existing reports on land natural resources inventory and planning, some studies on land use 
changes in Sudano-sahelian countries and general international literature.

The balance (difference between supply and demand) for land and water resources was estimated based on statistics data, using some equations described:

Local-scale studies in the Sudano-sahelian countries estimate an average of $250-375 \mathrm{~kg}$ of millet and sorghum production to feed an average person during 1 year ${ }^{[2,3,25]}$, In these countries, the diet is composed by cereals for up to $83-90 \%^{[19,26]}$ of the total consumption. In Mali the basic consumption requirements varies from one region to another. In Koulikoro Region it is $233 \mathrm{~kg}$ of grains inhabitant ${ }^{-1}$ year $^{-1}, 221 \mathrm{~kg}$ in Sikasso, $226 \mathrm{~kg}$ in Mopti ${ }^{[19]}$. The basic consumption of the Diamou population is estimated at an average value of $226 \mathrm{~kg}$ of grains per inhabitant ${ }^{[16]}$. The food consumption needs is measured by the population multiplied by the average consumption requirements of a person during one year. Thus, in year 1999 , it was $2849 * 226=643.874$ tonnes and in year 2010 it will be $3789 * 226=856.314$ tonnes. The projected population is estimated according to the general growth rate equation from the work of ${ }^{[8]}$ as:

$\mathrm{Pn}=\mathrm{Po} *(1+\mathrm{r})^{\mathrm{n}}$

Where:

$\mathrm{P}_{\mathrm{n}}=$ The population in year $\mathrm{n}$

Po $=$ The initial population

$\mathrm{R}=$ The birth rate

$\mathrm{N}=$ The number of years

Table 1: Crop yield $\left(\mathrm{kg}^{-1} \mathrm{ha}^{-1}\right)$

\begin{tabular}{|c|c|c|c|c|c|}
\hline \multirow[b]{2}{*}{ Cultivation } & \multirow{2}{*}{$\begin{array}{l}\text { Crop } \\
\text { area, } \\
\text { in ha }\end{array}$} & \multicolumn{3}{|c|}{ Yield kg ${ }^{-1} \mathrm{ha}^{-1}$} & \multirow{2}{*}{$\begin{array}{l}\text { Agricultural } \\
\text { output } \\
\text { (In tonne) }\end{array}$} \\
\hline & & Min & Average & Max & \\
\hline Sorghum & 427 & 367 & 571 & 775 & 244 \\
\hline Maize & 383 & 244 & 452 & 660 & 173 \\
\hline Millet & 301 & 248 & 399 & 550 & 120 \\
\hline Rice & 79 & 570 & 835 & 1100 & 66 \\
\hline Groundnut & 55 & 350 & 825 & 1300 & 45 \\
\hline Total & 1190 & & & & 603 \\
\hline
\end{tabular}

Note: Table data were used to estimate the cereal balance ${ }^{[3}$

Table 2: projected crop yield $\left(\mathrm{kg}^{-1} \mathrm{ha}^{-1}\right)$

\begin{tabular}{|c|c|c|c|c|c|}
\hline \multirow[b]{2}{*}{ Cultivation } & \multirow{2}{*}{$\begin{array}{l}\text { Crop } \\
\text { area, } \\
\text { in ha }\end{array}$} & \multicolumn{3}{|c|}{ Yield kg ${ }^{-1} \mathrm{ha}^{-1}$} & \multirow{2}{*}{$\begin{array}{l}\text { Production or } \\
\text { agricultural } \\
\text { output (In tonne) }\end{array}$} \\
\hline & & Min. & Aver. & Max. & \\
\hline Sorghum & 648 & 330 & 571 & 850 & 370 \\
\hline Maize & 383 & 244 & 452 & 660 & 173 \\
\hline Millet & 594 & 270 & 399 & 590 & 237 \\
\hline Rice & 79 & 570 & 835 & 1100 & 66 \\
\hline Groundnut & 65 & 350 & 850 & 1350 & 55 \\
\hline Total & 1640 & & & & 846 \\
\hline
\end{tabular}

The population growth rate various from 2.8$3 \%{ }^{[30]}$. For our case $\mathrm{r}$ is equal to 3 , Po equal to 2849 by substitution the formula (1) becomes simple, $\mathrm{Pn}=2849 *(1+3 \%)^{\mathrm{n}}$ Thus the population in year 2010 is approximately equal to 3789 inhabitants.

Agricultural output is measured by the cultivated area multiplied by the average crop yield (Table 1 and 2 ).

The drink water resources balance was calculate as follow: The domestic consumption per year by person is of $4 \mathrm{~m}^{3}$ in Mali, $106 \mathrm{~m}^{3}$ in France and $215 \mathrm{~m}^{3}$ in USA (source: "Water for people, water for life""[13] $4 \mathrm{~m}^{3}$ person $^{-1}$ year $^{-1}$ is our calculation basis. In Diamou in 1999th, there were 4 drillings or hand pump of which only1 was functional, 48 traditional wells dug. As we knew the total available water depended on outgoing water per hour and water collection time in hour, it is estimated as:

Wat $=(\mathrm{Dh} * \mathrm{Wh} * \mathrm{Tu})+($ Dwel. $*$ Wwel. $* \mathrm{Tu})$

Where:

Wat $=$ An available drink water

$\mathrm{Dh} / \mathrm{Dwel}=$ The number of hand pump or traditional wells

Wh = A hand pump outgoing water or flow rate $h^{-1}$

In Africa Hand pumps are the most common and, in most cases, the only economically feasible water lifting device for community needs. Yield depends on the depth and design, normally in the range of 600-1,500 $\mathrm{L} \mathrm{h} \mathrm{h}^{-1}$ during constant use. Thus, the maximum number of users for any one pump should, ideally, be not more than 150 persons. However in many countries and especially in Africa, the actual number of users per handpump is $500^{[13]}$. In our case $\mathrm{Dh}=1, \mathrm{Wh}=8001 \mathrm{~h}^{-1}$, Dwel. $=$ Wwel. $=70 \mathrm{~L} \mathrm{~h}^{-1}$ data from by substitution the formula (2) will be as:

$$
\begin{aligned}
\text { Wat }= & (1 * 800 * 12 * 365)+(48 * 70 * 12 * 365)= \\
& 3504000+14716800=18220800 \mathrm{~L} \\
\text { Wat }= & 18220800 \mathrm{~L} \text { or } 18220.8 \mathrm{~m}^{3}
\end{aligned}
$$

In 2010 , the water availability is estimated on the basis of four (4) hand pumps and 48 traditional wells dug. It is calculated as: Wat $=(\mathrm{Dh} * \mathrm{Wh} * \mathrm{Tu}), \mathrm{Dh}$ is a number of hand pump, Wh is a hand pump outgoing water or flow rate $\mathrm{h}^{-1}$, Tu is the use time, in our case $\mathrm{Dh}=4, \mathrm{Wh}=8001 \mathrm{~h}^{-1[13]}, \mathrm{Tu}=12 \mathrm{~h}(12 \mathrm{~h}$ an average time in many villages of Mali). Thus Wat $=8001 * 4 *$ $12 * 365=14016000 \mathrm{~L}$ or $14016 \mathrm{~m}^{3}$ as drink water, but the community will have water from traditional as: $48^{*}$ $701 * 12 * 365=14716.8 \mathrm{~m}^{3}$. The water consumption needs Qj is estimated as follow: 
$\mathrm{Qj}=\mathrm{q}(1 / \mathrm{j}) *$ No $/ 1000$

Where:

$\mathrm{q}(1 / \mathrm{j})=$ The water consumption person $^{-1}$ year $^{-1}$

No $=$ An initial population of Diamou in 1999 year

In our case $\mathrm{q}(\mathrm{l} / \mathrm{j})=4000$ or $4 \mathrm{~m}^{3^{[13]}} \mathrm{No}=2849$, by substitution $\mathrm{Qj}$ can be expressed as $\mathrm{Qj}=4 * 2849$ / $1000=11396 \mathrm{~m}^{3}$ or $11396000 \mathrm{~L}$. Eleven years after in 2010 the total water consumption needs: Qj in Diamou will be Qj $=4 \mathrm{~m}^{3} * 3789=15156 \mathrm{~m}^{3}$ or $15156000 \mathrm{~L}$.

One of the main characteristics of the pastoral land is its carrying capacity, defined as "the stocking number supported without range degradation, with livestock being well and taking weight" ${ }^{\text {[4] }}$. Depending on ecoclimatic zones, pastoral exploitation systems, estimates of average carrying capacity vary from 10 ha $\mathrm{TLU}^{-1}$ in drier years to 3.5 ha $\mathrm{TLU}^{-1}$ in normal years ${ }^{[4,23]}$. Actual measurements of carrying capacities are 2 ha $\mathrm{TLU}^{-1[16]}$ and 1.25 ha $\mathrm{TLU}^{-1[4,6]}$ :

$\mathrm{CC}=[\mathrm{Sp} . \mathrm{Bb} . \mathrm{K}] / \mathrm{Biomc}$

Where:

$\mathrm{Sp}=$ The pasture land area

$\mathrm{Bp}=$ The biomass production

$\mathrm{K}=$ The rate of this production it is possible to use without "any damage" to the pasture land or coefficient

$\mathrm{K}$, Biomc $=$ TLU biomass consumption needs year $^{-1}$

The average dietary requirements of a TLU are $6.25 \mathrm{~kg}$ of $\mathrm{DM}$ day $^{-1[4,6]}$. The international standard needs of one TLU is $2.5 \%$ of its weight, thus TLU biomass consumption needs $=250 \mathrm{~kg} * 2.5 / 100=$ $6.25 \mathrm{~kg} \mathrm{day}^{-1}$.

The production from shrubs and trees and crops residues also take part in the biomass consumption of the livestock ${ }^{[7,28]}$. According to the elaborated schema, the livestock can consume crops residues after harvesting. As saying up the pastoralism is extensive in Diamou. The total DM biomass required to satisfy the average biomass consumption of livestock is estimated as given by ${ }^{[28]}$ :

$$
6.25 \mathrm{~kg} * 365 * 3 * 2 / 3=4.6 \text { tonnes year }{ }^{-1} \mathrm{TLU}^{-1}
$$

The factor 3 accounts for the consumable fraction of above-ground biomass and the factor $2 / 3$ for the contribution of grasses to the consumption. In the intensification phase the later factor becomes $1 / 3$ (i.e., $2 / 3$ of the consumption is based on crop residues). In year 1999 the total biomass consumption is estimated as follow:
Biomc $=$ TLUn $*$ biomc

where, Tlun is the livestock number, biomc is a biomass consumption need $\mathrm{TLU}^{-1}$ (in ton), in our case the TLUn is equal to 553 and biomc is equal to 4.6 tonnes; thus Biomc $=2543.8$ tonnes, what can be arounded to 2544 tonnes.

Eleven years after (in 2010 year) the formula (5) will be as follow as in 1999 year Biomc = TLUn* biomc, TLUn will be equal to 233(transhumants will not be accepted in year 2010), 233 is the resident livestock population, biomc is equal to 4.6 tonnes, thus by substitution:

Biomc $=233 * 4.6=1071.8$ tonnes or 1072 tonnes

For many countries for example, the available data are statistically furnished by the great International Institutions. General opinion, these statistics are not very precious, as the reminder. The better methods to evaluate the pasture surface are the use of satellites images high resolution. In arid and semi arid zones the estimation of the surfaces of pasture land is liable of a relative imprecision of about $20 \%^{[4,29]}$. The corrected pasture land area $(\mathrm{Spc})$ is estimated as follow:

$\mathrm{Spc}=\mathrm{sp}-(20 \% * \mathrm{sp})$

sp was an existing pasture land. In our case sp is equal to 4590 ha, the formula 6 gave 3672 ha in year 1999 and 3060 ha in year 2010 .

Many authors think that biomass productivity in Sudano-sahelian grasslands only depends on rainfall $^{[20]}$, this is described by the following statistical relationship between dry matter biomass and rainfall:

$\mathrm{Bp}=0.15+0.00375 \mathrm{Ra}$

Where:

$\mathrm{Bp}=$ The biomass productivity in tones $\mathrm{ha}^{-1}$

$\mathrm{Ra}=$ The annual average of rainfall in $\mathrm{mm}$

In our case $\mathrm{Ra}=650 \mathrm{~mm}$, thus $\mathrm{Bp}$ is calculated as: $\mathrm{Bp}=0.15+0.00375 * 650=2$ tones $587 \mathrm{ha}^{-1}$, that can be around to 2 tones and $600 \mathrm{~kg}$. It probably will be the same in 2010 year. The total biomass productivity in 1999 year is estimated by total land area multiplied by the biomass productivity ha ${ }^{-1} .3672 * 2.600=9547$ tonnes, by the same way the total biomass productivity is projected to 2010 year, but the area (3825 ha after the statistic) is reduced of $20 \%$, thus by substitution: $\mathrm{Bp}=$ 3060 ha*2.600 $=7956$ tonnes. 
The coefficient $(\mathrm{K})$ corresponds to a rate of maximum exploitation of the aerial biomass, rate beyond of which the pastureland degradation becomes visible $^{[4,7]}$. The estimations relating to this coefficient are variable according to the types of pastureland and the livestock. In Sahelian region for example we use generally the standard of $33 \%$, but it can oscillate between 25 and $40 \%$. The value of $33 \%$ used in our case. Thus, the formula (4) is calculated as follow:

\section{$\mathrm{CC}=[\mathrm{Sp} \cdot \mathrm{Bp} \cdot \mathrm{K}] / \mathrm{Biomc}$}

In 1999 year, the pasture land area (Sp) was equal to $3672 \mathrm{ha}, \mathrm{Bp}$ was equal to 2.6 tones, $\mathrm{K}$ was equal to 0.33 , Biomc $=2543.8$ tones by substitution $\mathrm{CC}=(3672 * 2.6 *$ $0.33) / 2544=1.238$ ha TLU $^{-1}$. In 2010 year, Sp will be equal to $3825 \mathrm{ha}, \mathrm{Bp}$ will be equal to 2.6 tones, $\mathrm{K}$ will be equal to 0.33 , Biomc $=1072$ tones, by substitution $\mathrm{CC}=(3060 * 2.6 * 0.33) / 1072=2.449$ ha $^{2} \mathrm{TLU}^{-1}$.

The population of Diamou use fuel wood harvested from natural vegetation areas as its main energy source wood consumption and productivity in fuel wood are estimated by forest Inventor. Local-scale studies and regional surveys in the Sudano-sahelian region and in Diamou (MALI) estimate that $90 \%$ of the energy needs of households are covered by wood. An average one person uses a minimum of $1 \mathrm{~kg}$ of fuel wood day ${ }^{-1[5]}$. Some studies establish that the consumption needs vary from $0.5-1 \mathrm{~m}^{3}$ inhab $^{-1}$ year $^{-1[28]} 0.75 \mathrm{~m}^{3}$ fuel wood include the part as charcoal is an average value per inhabitant per year in Diamou in 1999 year is chosen for our estimation. The fuel wood consumption needs in 1999 year is estimated as follow: Fuelwc $=$ pop* 0.75, where Fuelwc is the fuel wood consumption needs year $^{-1}$, pop is the population of Diamou in 1999 year, $0.75 \mathrm{~m}^{3}$ is the consumption person ${ }^{-1}$ year $^{-1}$, by simple replacement fuelwc $=2849 * 0.75 \mathrm{~m} 3=2136.75 \mathrm{~m}^{3}$. The productivity of the shrub savannah in Sho (Koulikoro) is estimated at an average value of $0.911 \mathrm{~m}^{3} \mathrm{ha}^{-1[5,28]}$ he same value is used in Diamou because of the presence of the same land cover type (shrub savannah). Our natural vegetation land productivity is calculated as follow:

$\mathrm{Py}=\mathrm{A} * 0.911$

Where:

Py $=$ The woodland productivity

$\mathrm{A}=$ The fuel wood extraction area

For our case, where A was equal to 318 ha and 0.911 is the woody biomass productivity per hectare the formula (8) became simply: $\mathrm{Py}=318 * 0.911=$ $289.69 \mathrm{~m}^{3} \mathrm{ha}^{-1}$ year $^{-1}$. The corrected fuelwood consumption needs is calculated as follow: Fuelwc $=(\text { fuelwa/Yn })^{*} 0.911$ where fuewa is an fuelwood extraction area, Yn, the number of projected year and 0.9110 .911 is the woody biomass productivity per hectare By substitution the parameters fuelwc by substation fuel $(318 / 11) * 0.911=26.32 \mathrm{~m}^{3}$ year $^{-1}=$ 28.90 ha. In year 2010 the fuelwood consumption needs (fuelwc) is measured by the population multiplied by the consumption person ${ }^{-1}$ year $^{-1}$ :

pop* 0.75

where, pop is the population of Diamou in 2010 year, $0.75 \mathrm{~m}^{3}$ is the consumption need person $^{-1}$ year $^{-1}$, by sampling replacement fuelwc will be as: Fuelwc $=3789 * 0.75 \mathrm{~m}^{3}=3788.25 \mathrm{~m}^{3}$ or 3451.09 ha our schrub savanna productivity is equal to $0.911 \mathrm{~m}^{3} \mathrm{ha}^{-1}$. The woodland productivity of the territory of Diamou will be as follow as in year 1999, $\mathrm{Py}=\mathrm{A}^{*} 0.911$ where, $\mathrm{Py}$ is the woodland productivity, $\mathrm{A}$ is the fuelwood extraction area, it's equal to $1083 \mathrm{ha}$ in our case and 0.911 is the woody biomass productivity $\mathrm{ha}^{-1}$. by simple replacement Py will be Py $=1083 * 0.911=986.613 \mathrm{~m}^{3} \mathrm{ha}^{-1}$.

The resources balances diagram are drawn using Microsoft word command chart and the land use sketch or scheme using arcGIS. The land partition was done according to the importance of each land use activity.

\section{RESULTS}

Figure 2 shows the cereal and biomass balances in 1999. The first was negative because cereal consumption needs where higher (644 tonnes) than agricultural land output (603 tonnes). Table 1 and 2 represent the agricultural land output in years 1999 and 2010 respectively. The second was positive because the livestock consumption needs was lower than biomass productivity. Figure 3 shows the drink water and fuel wood balances in year 1999. The drink water availability and its consumption needs were around equal to $18221 \mathrm{~m}^{3}$ and $11396 \mathrm{~m}^{3}$ respectively. The balance was positive. The fuel wood consumption needs and its productivity were roughly equal to 2137 $\mathrm{m}^{3}$ and $290 \mathrm{~m}^{3}$, respectively. Except the biomass balance in year 2010, all the resources balance were negative (Fig. 4 and 5). The distribution of the land use activities in year 1999, is shown in (Fig. 6). There are cropland, pastureland and fuel wood extraction land. 


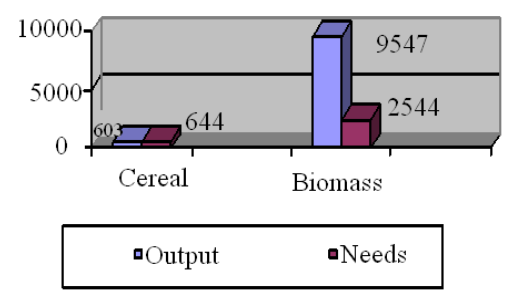

Fig. 2: Cereal and biomass balances in year 1999

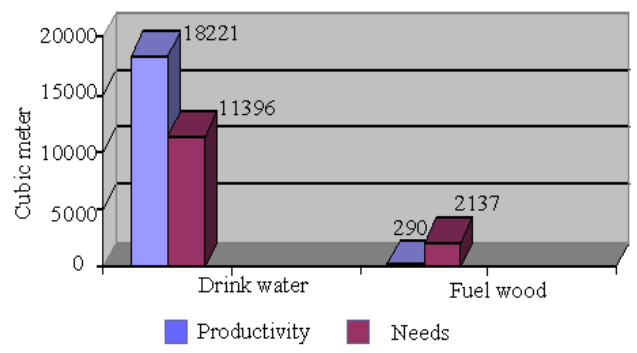

Fig. 3: Drink water and fuel wood balances in year 1999

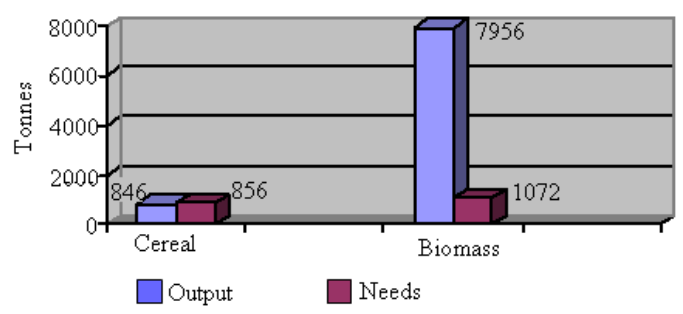

Fig. 4: Cereal and biomass balances in year 2010

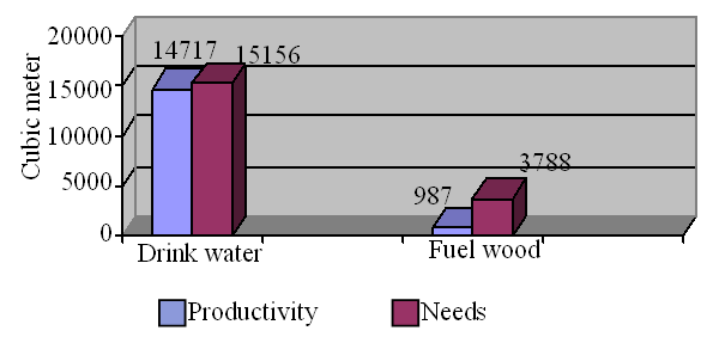

Fig. 5: Drink water and fuel wood balances in year 2010

The drink water and fuel wood deficits were particularly high and were equal to $439 \mathrm{~m}^{3}$ and $2801 \mathrm{~m}^{3}$ respectively. The dominant land use categories were the pasture and cropland, occupying about 52 and $45 \%$ of the total area (8876 ha). Figure 7 shows the land use types distribution of the whole study area, where the dominant land use class was the cropland (3968 ha),

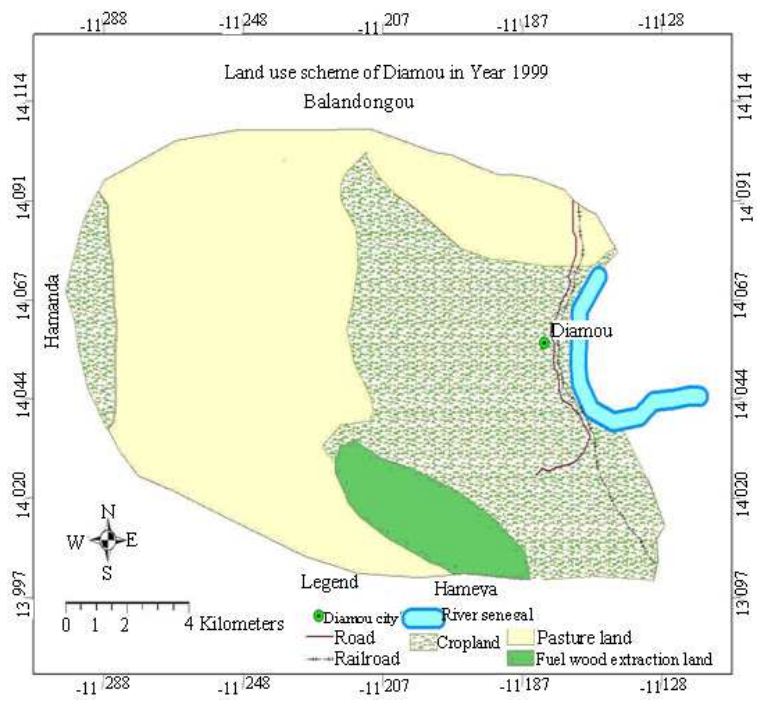

Fig. 6: Land use Scheme of Diamou in year 1999

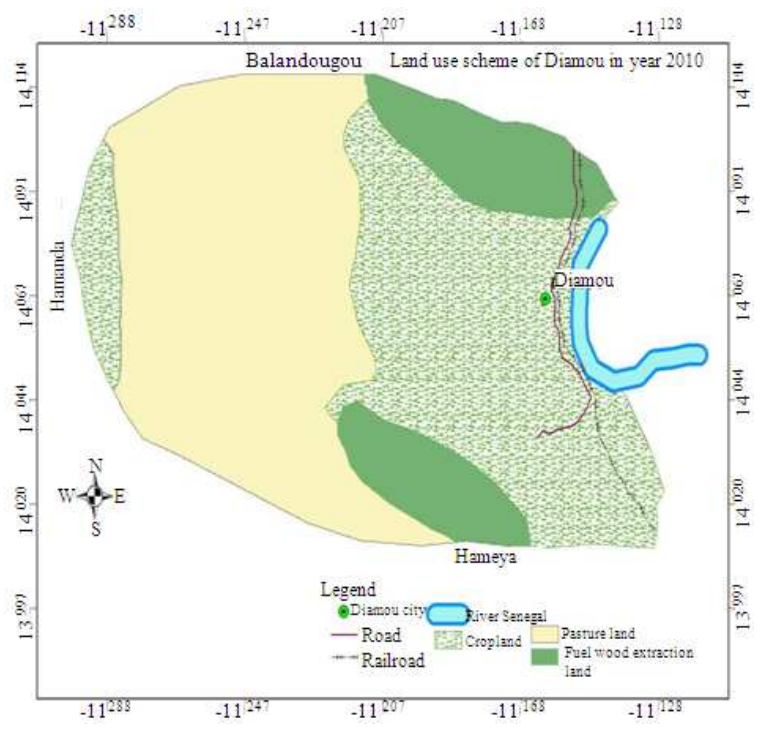

Fig. 7: Land use scheme of Diamou in year 2010

which covered approximately $45 \%$ of total area (8876 ha), whereas the pasture land (3825 ha) and a fuel wood extraction land( 1083 ha) occupying 43 and $12 \%$ of total area, respectively.

\section{DISCUSSION}

From the results the negative cereal balance in both years 1999 and 2010 (Fig. 2 and 4), may due to many factors among which the extensive agriculture, the poorest of the soils an $\mathrm{P}$ and $\mathrm{N}$. After $\mathrm{P}, \mathrm{N}$ is the most limiting nutrient for grain crops in the Sahel ${ }^{[12,22]}$. 
Others researchers reported: Soils in the Sahel are inherently fragile, low in carbon and poor in plants nutrients ${ }^{[24,27]}$. Knowledge of soil $\mathrm{N}$ dynamics is essential for effective crop management and fertilizer recommendations, Nitrogen mineralization and nitrification are usually very slow in the field during the dry season, but dramatically increase once the rains commence ${ }^{[26,27]}$. Following rewetting of dried soil, $\mathrm{N}$ is often rapidly mineralized during the first 1-2 weeks and approaches steady-state conditions thereafter ${ }^{[11,12,24]}$. The wetting and drying of soil is the essential cause of the $\mathrm{N}$ flush. As outcome the crop yield were very low (Table 1 and 2). Those yield were found to be inconsistent with the ranges reported elsewhere ${ }^{[3,26]}$. But we know from the literature the fertility of soils is not only determined by their nutrient stock, but also by their structure as well as by their flora and fauna.

The positive biomass balance, can be explained by the actual carrying capacity of the study area ( 2.44 ha $\left.\mathrm{TLU}^{-1}\right)$. That was consistent with the ranges given by ${ }^{[6,23]}$. The positive drink water balance, could be attributed to well-dug water consumption even if that can be source of illness because of some well-dug contamination in year 1999. Its negative balance in 2010 was not a revelation in the Sahelian country. It might due to fact that the human population abandoned the well and appreciated the potable water of the pump, which were not enough to satisfy their consumption needs. The negative fuel wood balance (Fig. 3 and 5) for both year 1999 and 2010 could be attributed to its high consumption needs as only source of energy. Despite the extension of its land area, the balance was remained negative. An average one person uses a minimum of $1 \mathrm{~kg}$ of fuelwood $\mathrm{day}^{-1}$. That was found high in the Sahel country but it was lower than the mean annual consumption in southern Africa, where ${ }^{[9]}$ the mean annual consumption was estimated at $4343 \mathrm{~kg} \mathrm{user}^{-1}$ household, or $692 \mathrm{~kg}$ capita $^{-1}$ annum $^{-1}$, ranging from 264-1699 kg. As consequence, the forest was overexploited and its productivity diminished with the time. Some authors already noted that, at the exception of critical situations, one generally observes a sustainable use of natural vegetation resources in the Sudano-Sahelian region ${ }^{[10,18]}$. This case can be similar to the situation in Mrijo Chini (Tanzani), where people have to walk 5-10 km to collect wood ${ }^{[1,9]}$.

In the current version of the Scheme (Fig. 6 and 7), the size of each land use class is equivalent to its importance for the community. But the pastureland area was wide to prevent conflict between pastoralist and farmers. The size of the cropland was equivalent to its importance as the first economic activity. The pastorlism was the second. The fuel wood extraction land (Fig. 6 and 7) was extended to satisfy the consumption needs of the community and to protect some rare plants species from livestock overgrazing.

\section{CONCLUSION}

The first conclusion that can be drawn from this study is that the land resources are finite and that whatever the population pressure is, the tendency is towards an over-exploitation of the resource base, which justifies our fears. Studies have indicated the cereal, fuel wood and drink water deficit in years 1999 and 2010.

Two conditions must be met if sustainable use of resources is to be useful:

- The need for changes in use of fuel wood and drink water

- There must be ability to manage the development of agriculture

\section{ACKNOWLEDGEMENT}

China Scholarship Council and China University of Geosciences supported this study.

\section{REFERENCES}

1. Amler, B., D. Betke, H. Eger, C. Ehrich, A. Kohler, A. Kutte, von A. Lossau, U. Müller, S. Seidemann, R. Steurer and W. Zimmermann, 1999. Land Use Planning Methods, Strategies and Tools, Deutsche Gesellschaft für Technische Zusammenarbeit (GTZ) GmbH. http://www.gtz.de/de/dokumente/en-lup-engl.pdf

2. Anneke de Rouw and Jean-Louis Rajot, 2004. Nutrient availability and pearl millet production in Sahelian farming systems based on manuring or fallowing. Agric. Ecosyst. Environ., 104: 249-262. DOI: 10.1016/J.AGEE.2003.12.019

3. Aune, B., Jens and A. Bationo, 2008 Agricultural intensification in the Sahel. The ladder approach Agric. Syst., 98: 119-125.

DOI: 10.1016/J.AGSY.2008.05.002

4. Oumarou, B., S.O. Claudio, J.W. Jones, R. Nelson, K. Amadou and K. Moussa, 2007. A simulation-based analysis of productivity and soil carbon in response to time-controlled rotational grazing in the West African Sahel region. Agric. Syst., 94: 87-96.

DOI: 10.1016/J.AGSY.2005.09.010 
5. Benjaminsen, T.A., 1993. Fuelwood and desertification: Sahel orthodoxies discussed on the basis of field data from the gourma region in Mali. Geoforum, 24: 397-409.

http://direct.bl.uk/bld/PlaceOrder.do?UIN=011805 $012 \&$ ETOC $=$ EN\&from $=$ searchengine

6. De, L.P.N. and J.C. Tothill, 1993. The Concept of Carrying Capacity in Sub-Saharan Africa: Myth or reality? In: Range Ecology at Disequilibrium: New Models of Natural Variability and Pastoral Adaptation in African Savannas. Behnke R.H., I. Scoones and C. Kerven (Eds.). Overseas Development Institute, London, UK., pp: 77-88.

7. Delve, R.J., G. Cadisch, J.C. Tanner, W. Thorpe, P.J. Thorne and K.E. Giller, 2001. Implications of livestock feeding management on soil fertility in the smallholder farming systems of sub-Saharan Africa. Agric. Ecosyst. Environ., 84: 227-243. DOI: 10.1016/S0167-8809(00)00244-9

8. Dewi, S. and P. Chesson, 2004. Age-structured population growth rates in constant and variable environments: A near equilibrium approach. Theor. Popul. Biol., 65: 75-88. DOI: 10.1016/j.tpb.2003.09.002

9. Dovie B.D.K., C.M. Shackleton, E.T.F. Witkowski and C.M. Shackleton, 2004. The fuelwood crisis in southern Africa-relating fuelwood use to livelihoods in a rural village. Geo J., 60: 123-133. DOI: 10.1023/B:GEJO.0000033597.34013.9f

10. Fearnside, P.M., 2001. Saving tropical forests as a global warming countermeasure: An issue that divides the environmental movement. Ecol. Econ., 39: $167-184$.

DOI: $10.1016 / \mathrm{S} 0921-8009(01) 00225-7$

11 Franzluebbers et al., 1995. Nitogen dynamics in tropical soils of Mali, West Africa. Biol. Fertil. Soils, 39: 258-268.

DOI: $10.1007 / \mathrm{s} 00374-003-0718-\mathrm{y}$

12 Ghoshal, N., 2002 Available pool and mineralization rate of soil $\mathrm{N}$ in a dryland agroecosystem: Effect of organic soil amendment and chemical fertiliz. Trop. Ecol., 43: 363-366. http://www.tropecol.com/pdf/open/PDF_43_2/432 17.pdf

13 Gleitsmann, A. Brett, Kroma M., Margaret and T. Steenhuis, 2007. Analysis of a rural water supply project in three communities in Mali: Participation and sustainability. Natural Resourc. Forum, 31: 142-150.

http://soilandwater.bee.cornell.edu/publications/Gl eitsmannNRF07.pdf
14 Guyer, J.I. and E.F. Lambin, 1993. Land-use in an urban hinterland: Ethnography and remote sensing in the study of African intensification. Am. Anthropol., 95: 839-859.

http://www.igsnrr.ac.cn/lwzzImg/1235093625204.pdf

15. Hellden, U., 1991 Desertification time for an assessment. Ambio, 20: 372-383. http://www.nateko.lu.se/Elibrary/LeRPG/3/3Article.htm

16. Horowitz, M. and M. Salem-Murdock, 1993. Development-induced food insecurity in the middle Senegal Valley. Geo J., 30: 179-184. http://www.springerlink.com/content/nt38m883581 3716u/fulltext.pdf

17 Hulme, M., 1996. Recent climatic changes in the world's drylands. Geophys. Res. Lett., 23: 61-64. http://www.agu.org/pubs/crossref/1996/95GL0358 6.shtml

18 Ite, U.E. and W.M. Adams, 1998. Forest conversion, conservation and forestry in Cross River State Nigeria. Appl. Geogr. 18: 301-314. http://www.citeulike.org/group/344/article/148425

19 Jindra, C., 1993. Famine coping strategies in central mali. Gee J., 30: 147-151. DOI: 10.1007/BF00808131

20 Kay, R.N.B., 1997. Responses of African livestock and wild herbivores to Drought. J. Arid Environ., 37: 683-694. DOI: 10.1006/JARE.1997.0299

21 Lambin, E., 1997. Modeling and monitoring land-cover change processes in tropical regions. Progr. Phys. Geogr., 21: 375-393. http://ppg.sagepub.com/cgi/reprint/21/3/375

22. Manlay, R.J., J.L. Chotte, D. Masse, J.Y. Laurent and C. Feller, 2002. Carbon, nitrogen and phosphorus allocation in agro-ecosystems of the West African savanna III. Plant and soil components under semi-permanent cultivation. Agric. Ecosyst. Environ., 88: 249-269. DOI: 10.1126/science.1099893, 1627 (2004)

23. Olsson, K. and A. Rapp, 1991. Dryland degradation in central Sudan and conservation for survival. Ambio, 20: 192-195. http://ambio.allenpress.com/perlserv/?request=linkresolver\&cite_doi=0044-7447(1991)020\%5B0192 \%3ADDICSA\%5D2.0.CO\%3B2\&id=I0044-744731-6-471-B20\&ct=1

24. Pandey, C.B., R.B. Rai and L. Singh, 2007. Seasonal dynamics of mineral $\mathrm{N}$ pools and $\mathrm{N}$-mineralization in soils under homegarden trees in South Andaman. India Agrofor. Syst., 71: 57-66. DOI: $10.1007 / \mathrm{s} 10457-007-9073-6$ 
25. Reij, C., G. Tappan and A. Belemvire, 2005. Changing land management practices and vegetation on the Central Plateau of Burkina Faso (1968-2002). J. Arid Environ., 63: 642-659. DOI: 10.1515/IABI.2005.272, 24/April/2006

26. Shahandeh, H., B.S. Knewtson, M. Doumbia and H.F.L. Hossner, 2004. Nitrogen dynamics in tropical soils of Mali, West Africa. Biol. Fertil. Soils, 39: 258-268.

DOI: 10.1007/s00374-003-0718-y

27. Singh, J.S. and A.K. Kashyap, 2006. Dynamics of viable nitrifier community, $\mathrm{N}$-mineralization and nitrification in seasonally dry tropical forests and savanna. Microbiol. Res., 161: 169-179. DOI: 10.1016/j.micres.2005.07.009
28. Stéphenne, N. and E.F. Lambin, 2001. A dynamic simulation model of land-use changes in Sudano-sahelian countries of Africa (SALU). Agric. Ecosyst. Environ., 85: 145-161. DOI: 10.1016/S0167-8809(01)00181-5

29. Stéphenne, N. and E.F. Lambin, 2004. Scenarios of land-use change in Sudano-sahelian countries of Africa to better understand driving forces. Geo J., 61: 365-379. DOI: 10.1007/s10708-004-5053-9

30. Yohannis, A., 2000. African population growth and politics, Afr. Stud. Assoc., 8: 14-19. http://www.jstor.org/stable/1166318 